\title{
"Ship-in-bottle" strategy to encapsulate shape-controllable metal nanocrystals into metal-organic frameworks: internal space matters
}

Yang Wang ${ }^{1 *}$, Lianjie Ling ${ }^{1}$, Wei Zhang ${ }^{1}$, Jianping Guo ${ }^{2}$, Kejian Ding ${ }^{1}$, Wubiao Duan ${ }^{1}$, Bo Liu ${ }^{1 *}$

1. Department of Chemistry, School of Science, Beijing Jiaotong University, Beijing 100044, People's Republic of China;

2. State Key Laboratory of Solid Wastes Resource Utilization and Energy Saving Building Materials, Beijing Building Materials Academy of Science Research, 100041 Beijing, China

"Corresponding author.E-mail: vangwang6270@gmail.com; boliu@bjtu.edu.cn 
(a)

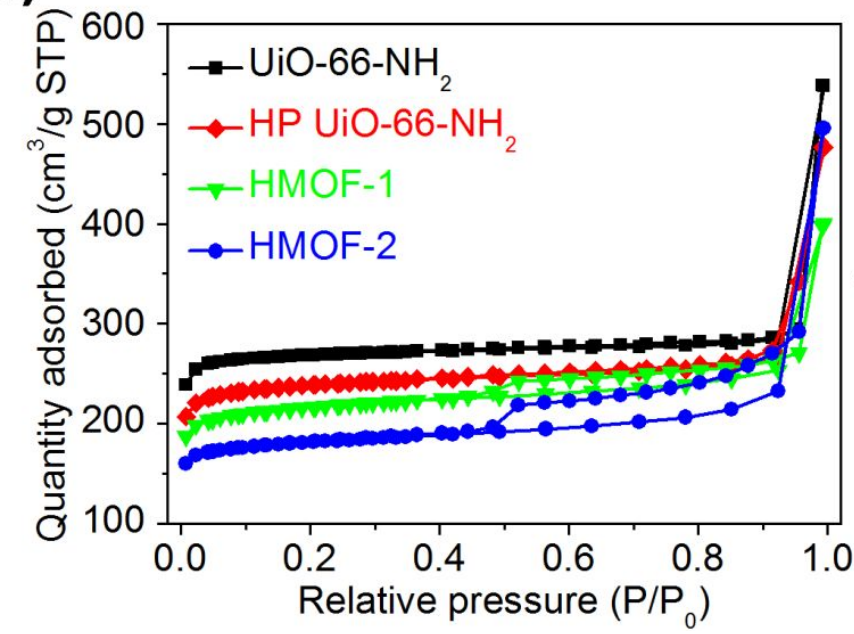

(b)

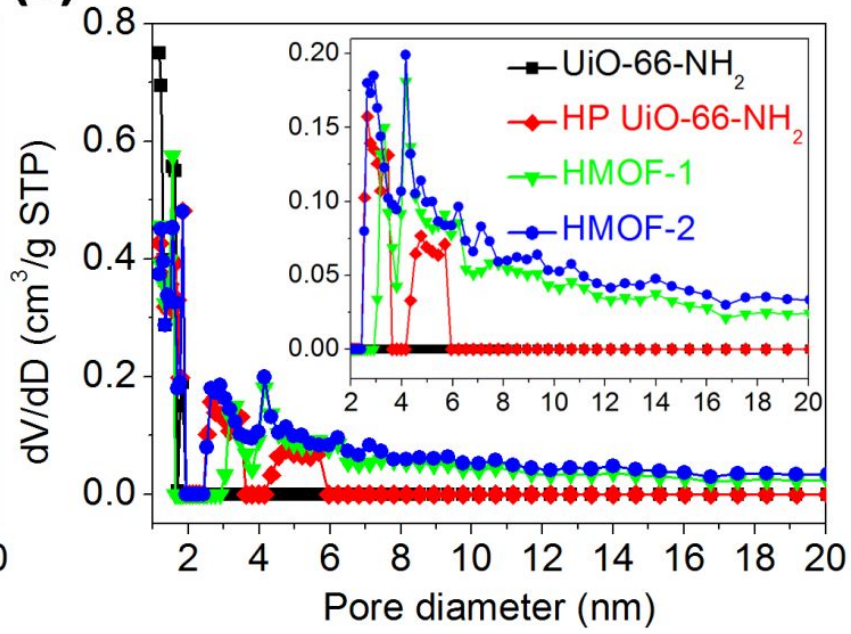

Fig. S1. $\mathrm{N}_{2}$ sorption isotherms (a) and pores distribution (b) calculated by DFT method of UiO-66- $\mathrm{NH}_{2}, \mathrm{HP}$ UiO-66-NH $\mathrm{N}_{2}$, HMOF-1 and HMOF-2.

Table S1. Summary of BET surface area, pore features of as-prepared samples

\begin{tabular}{|c|c|c|c|}
\hline Samples & BET surface $\left(\mathrm{m}^{2} / \mathrm{g}\right)$ & Pore volume $\left(\mathrm{cm}^{3} / \mathrm{g}\right)$ & Average Pore Diameter (nm) \\
\hline $\mathrm{UiO}-66-\mathrm{NH}_{2}$ & 1045 & 0.43 & 1.71 \\
\hline HP UiO-66-NH ${ }_{2}$ & 902 & 0.51 & 2.53 \\
\hline HMOF-1 & 816 & 1.06 & 3.80 \\
\hline HMOF-2 & 528 & 1.13 & 4.12 \\
\hline
\end{tabular}




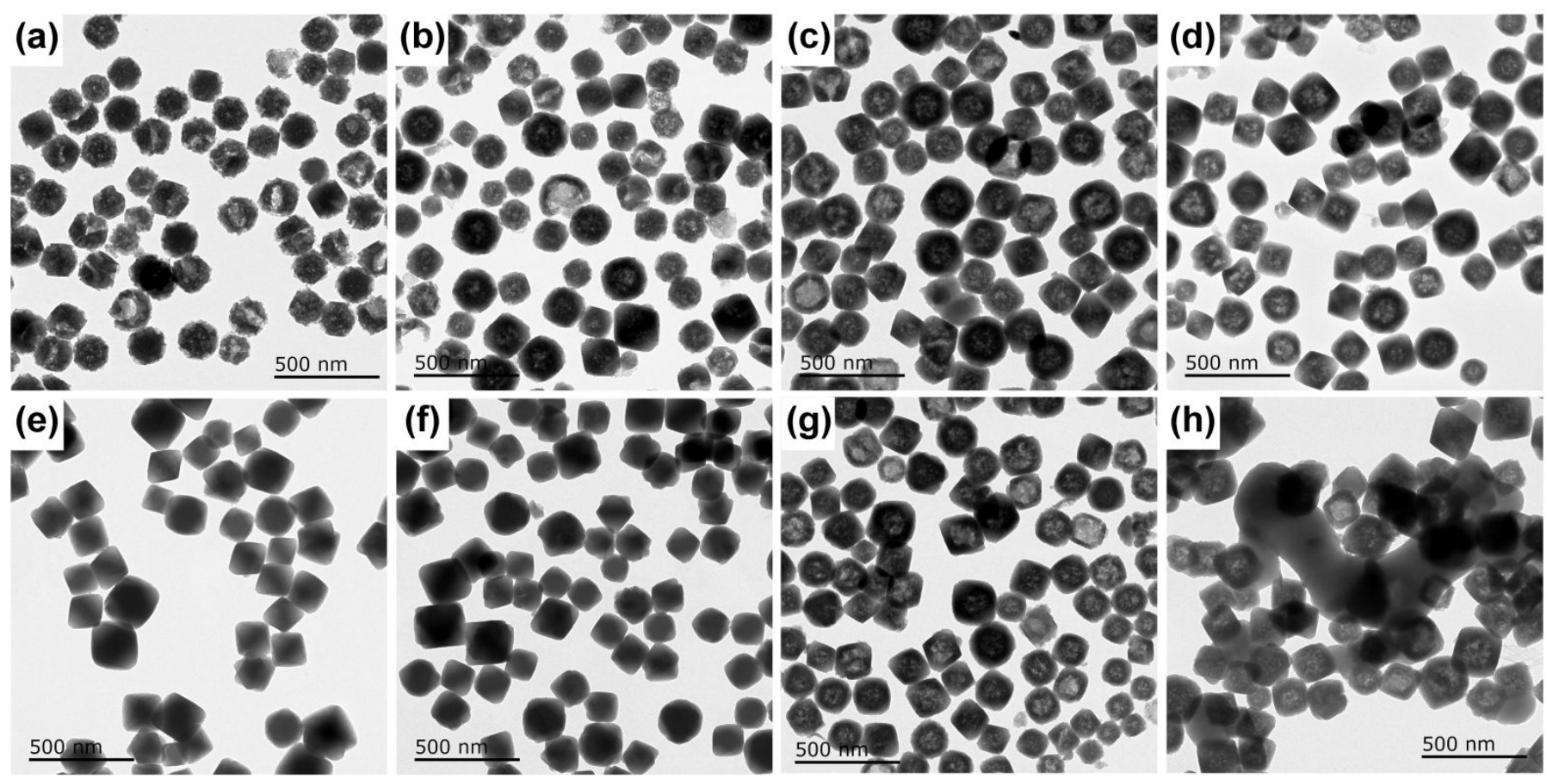

Fig.S2. TEM images of pristine UiO-66- $\mathrm{NH}_{2}$ treated by $0 \mathrm{~mL}$ acetone (a), $1 \mathrm{~mL}$ acetone (b), $10 \mathrm{~mL}$ acetone (c), $25 \mathrm{~mL}$ acetone (d), $50 \mathrm{~mL}$ acetone (e) at the condition of $30 \mathrm{~mL}$ water, $50 \mathrm{mg} \mathrm{UiO}-66-\mathrm{NH}_{2}, 1 \mathrm{~mL}$ nitric acid heated at $150{ }^{\circ} \mathrm{C}$ for 10 $\mathrm{h}$ to produce HMOF-1, $30 \mathrm{~mL}$ of pure acetone as solvent without water (f) and $30 \mathrm{~mL}$ water, $25 \mathrm{~mL}$ acetone, $50 \mathrm{mg}$ UiO-66- $\mathrm{NH}_{2}, 1 \mathrm{~mL}$ nitric acid heated at $150^{\circ} \mathrm{C}$ for $1 \mathrm{~h}(\mathrm{~g})$ and $24 \mathrm{~h}(\mathrm{~h})$.

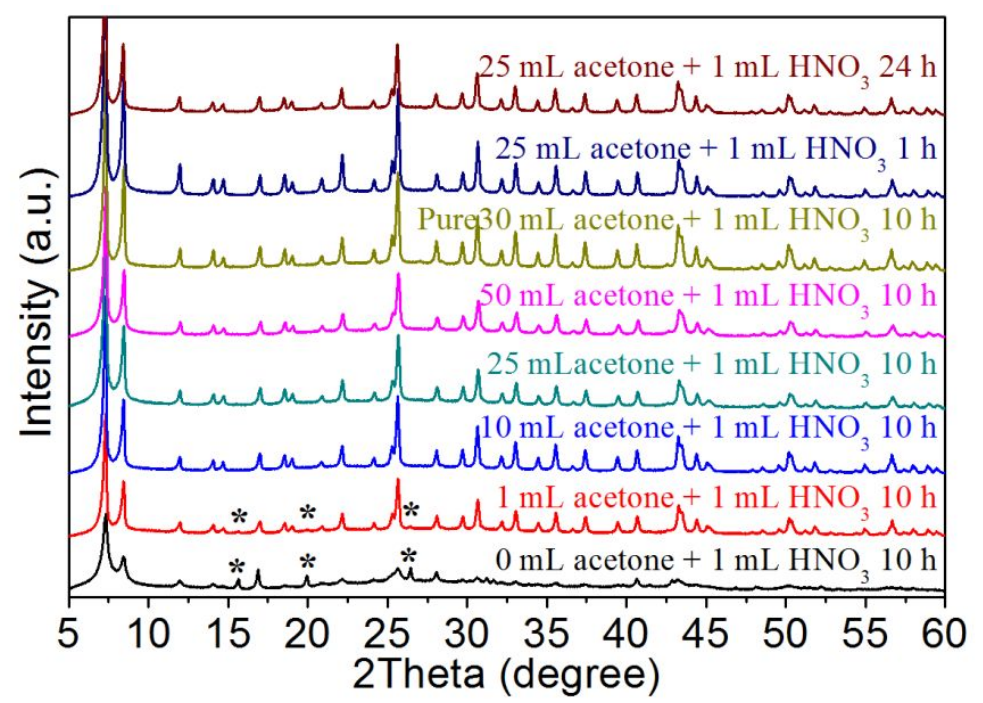

Fig.S3. XRD patterns of the samples when exploring conditions to produce HMOF-1, the patterns are corresponding to the figures in Fig. S2. 


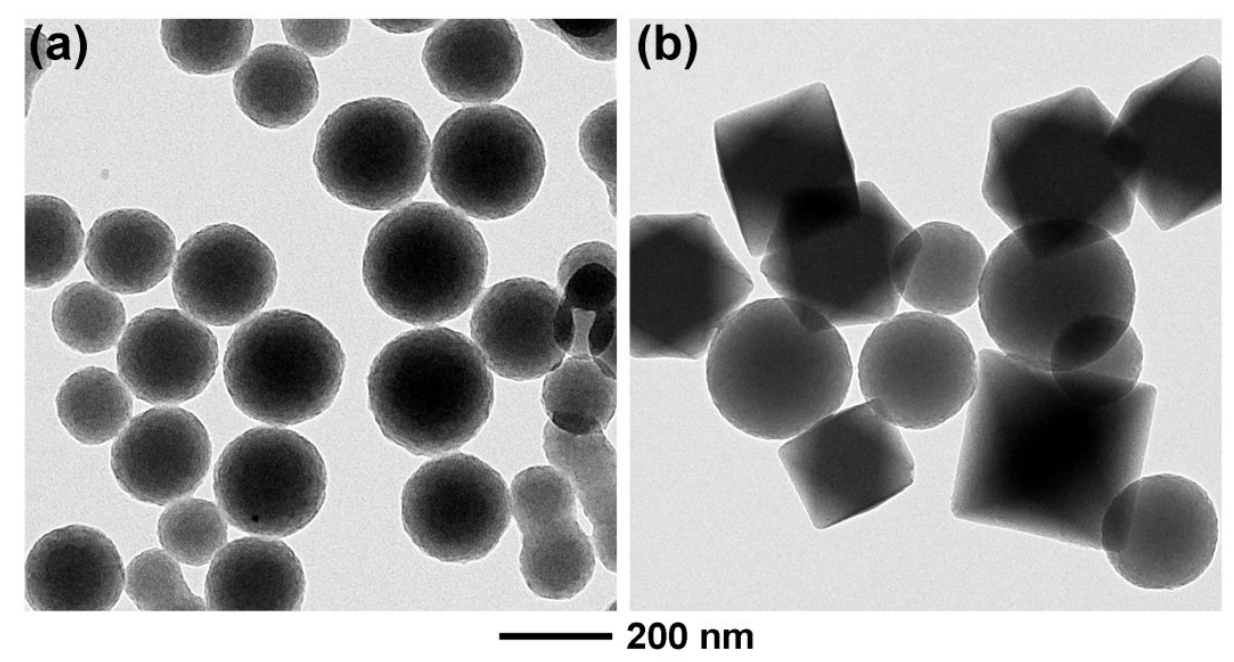

Fig.S4. TEM images of as-prepared "protective agent" of colloidal carbons (a), UiO-66- $\mathrm{NH}_{2} /$ colloidal carbons hybrid (b).

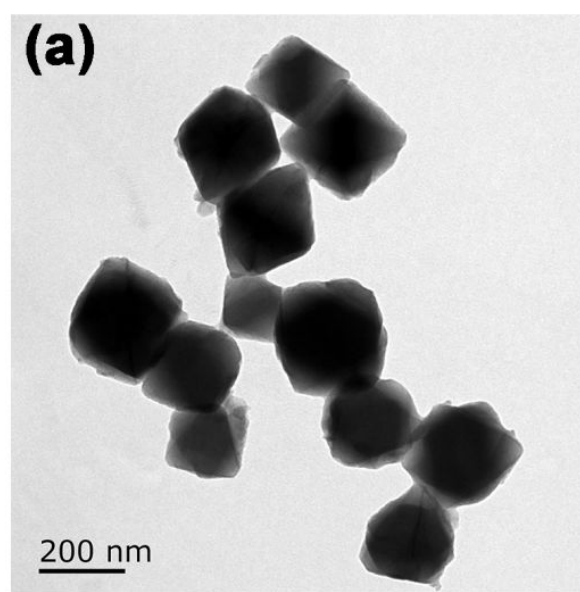

(b)

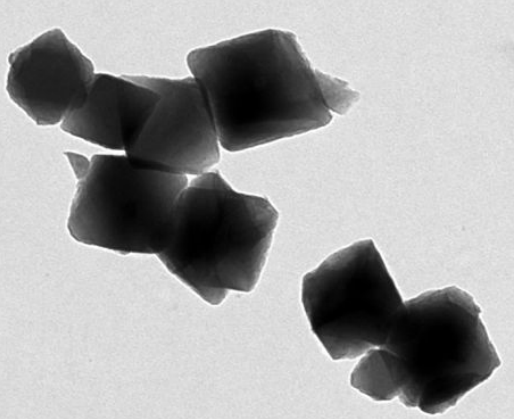

$200 \mathrm{~nm}$

(d)

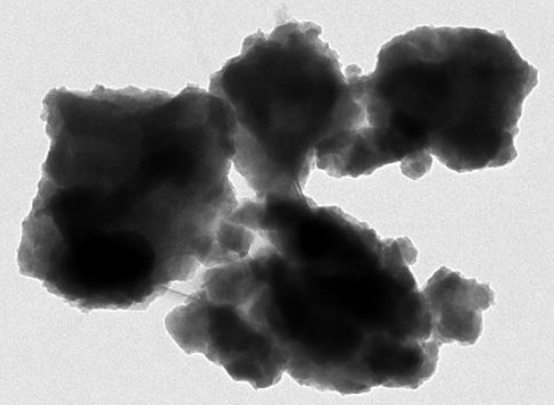

$200 \mathrm{~nm}$

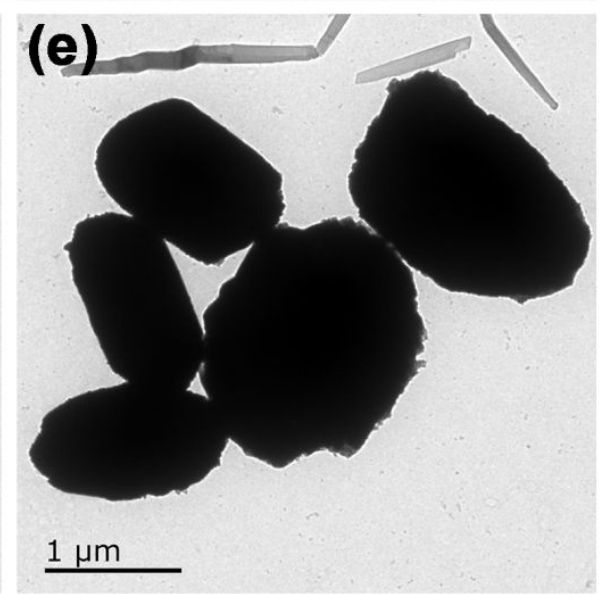

(c)

$200 \mathrm{~nm}$

(f)

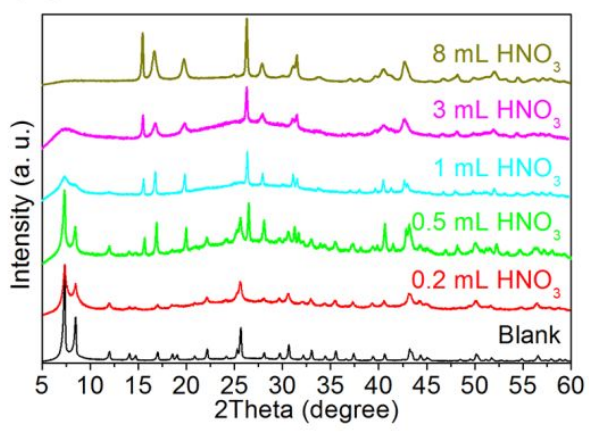

Fig.S5. TEM images of $50 \mathrm{mg}$ pristine UiO-66- $\mathrm{NH}_{2}$ treated by different amounts of nitric acid: $0.2 \mathrm{~mL}$ (a), $0.5 \mathrm{~mL}$ (b), 1 $\mathrm{mL}$ (c), $3 \mathrm{~mL}$ (d) and $8 \mathrm{~mL}$ (e) in $30 \mathrm{~mL}$ water and heated at $150{ }^{\circ} \mathrm{C}$ for 4 hours and the corresponding XRD patterns (f). 

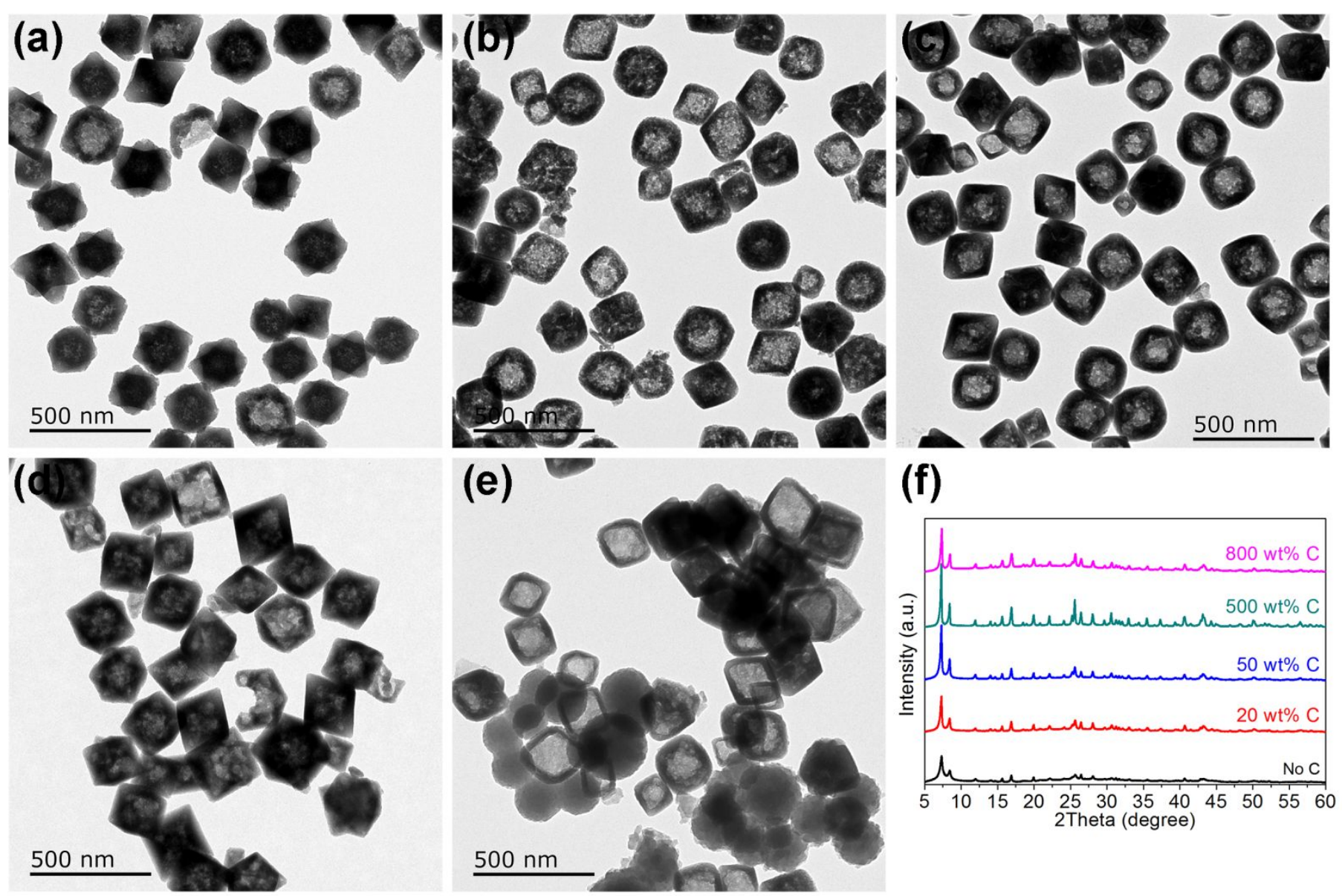

(f)

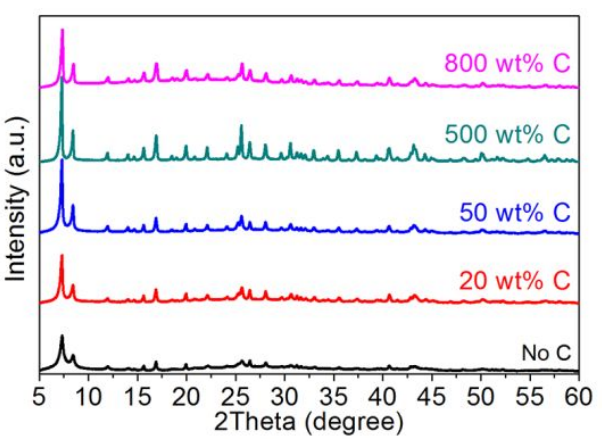

Fig.S6. TEM images of pristine UiO-66- $\mathrm{NH}_{2}$ treated by different amounts of colloidal carbons: 0 (a), $20 \mathrm{wt} \%$ (b), $50 \mathrm{wt} \%$ (c), $500 \mathrm{wt} \%$ (d) and $800 \mathrm{wt} \%$ (e) at the condition of $30 \mathrm{~mL}$ water, $50 \mathrm{mg}$ UiO-66- $\mathrm{NH}_{2}, 1 \mathrm{~mL}$ nitric acid and heated at 150 ${ }^{\circ} \mathrm{C}$ for 4 hours to produce HMOF-1 and corresponding XRD patterns (f). 

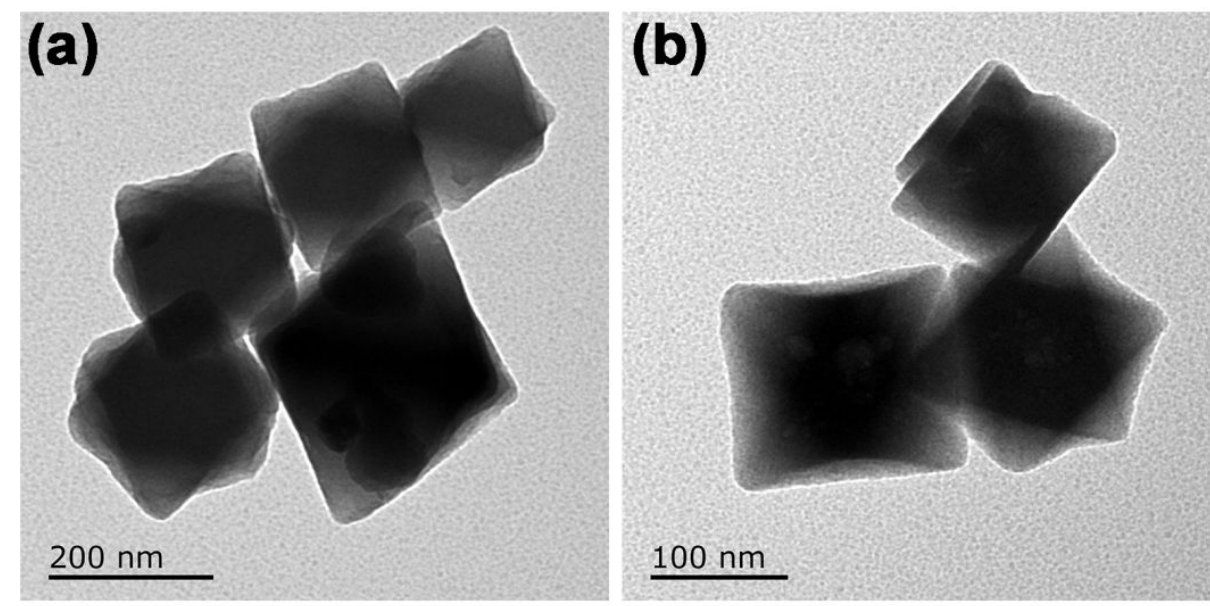

\section{(c)}
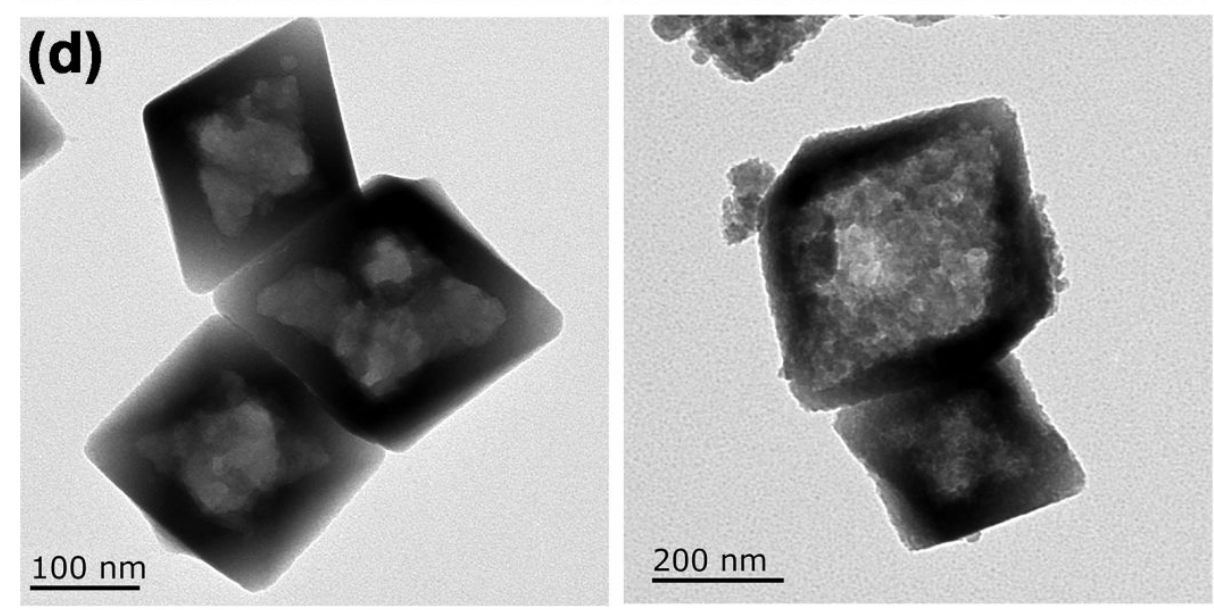

\section{$\underline{200 \mathrm{~nm}}$}

\section{(f)}

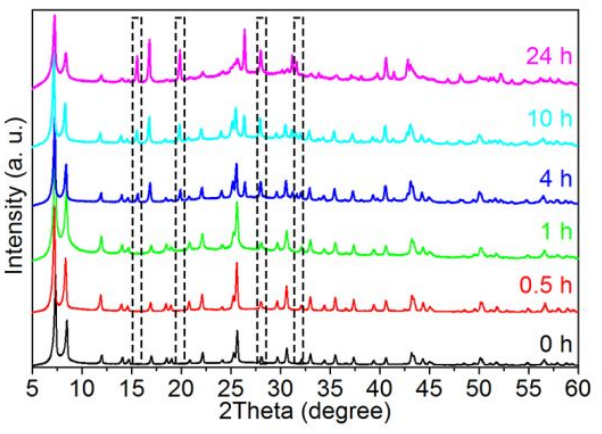

Fig.S7. TEM images of pristine UiO-66- $\mathrm{NH}_{2}$ treated by different times: $0.5 \mathrm{~h}(\mathrm{a}), 1 \mathrm{~h}(\mathrm{~b}), 4 \mathrm{~h} \mathrm{(c)}, 10 \mathrm{~h}(\mathrm{~d})$ and $24 \mathrm{~h}(\mathrm{e})$ at the condition of $30 \mathrm{~mL}$ water, $50 \mathrm{mg}$ UiO-66- $\mathrm{NH}_{2}, 25 \mathrm{mg}$ colloidal carbons, $1 \mathrm{~mL}$ nitric acid heated at $150{ }^{\circ} \mathrm{C}$ to produce HMOF-1 and the corresponding XRD patterns (f). 


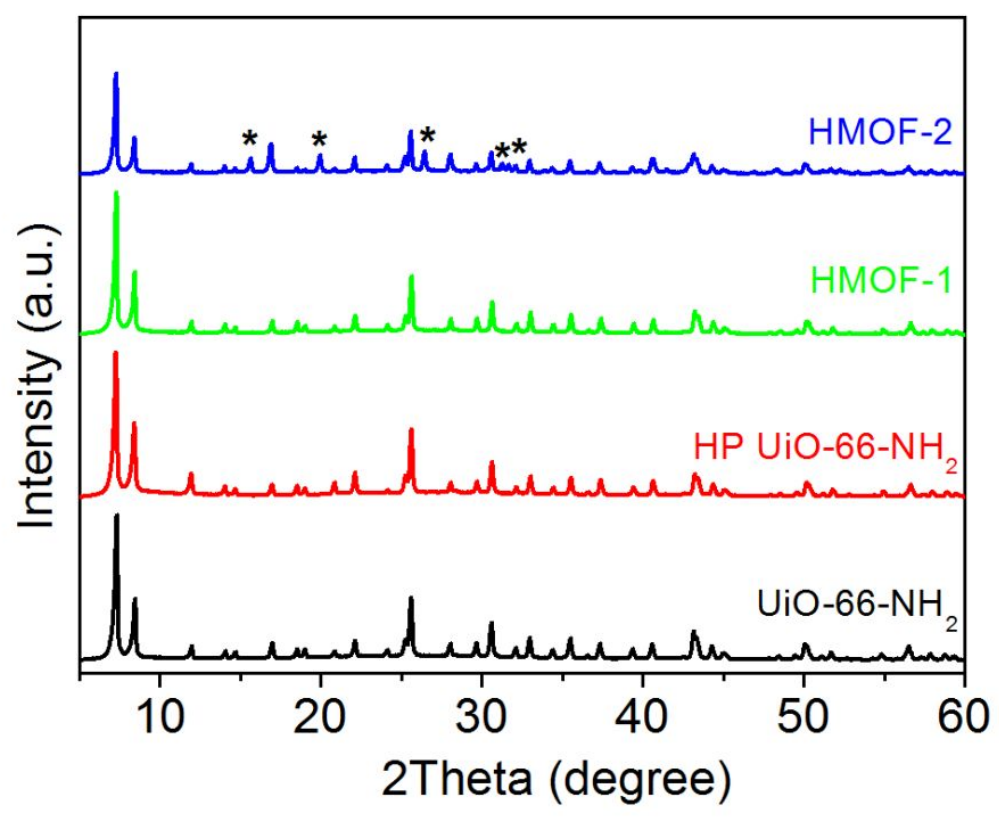

Fig.S8. XRD patterns of pristine UiO-66- $\mathrm{NH}_{2}$, HP UiO-66-NH 2 , HMOF-1 and HMOF-2.
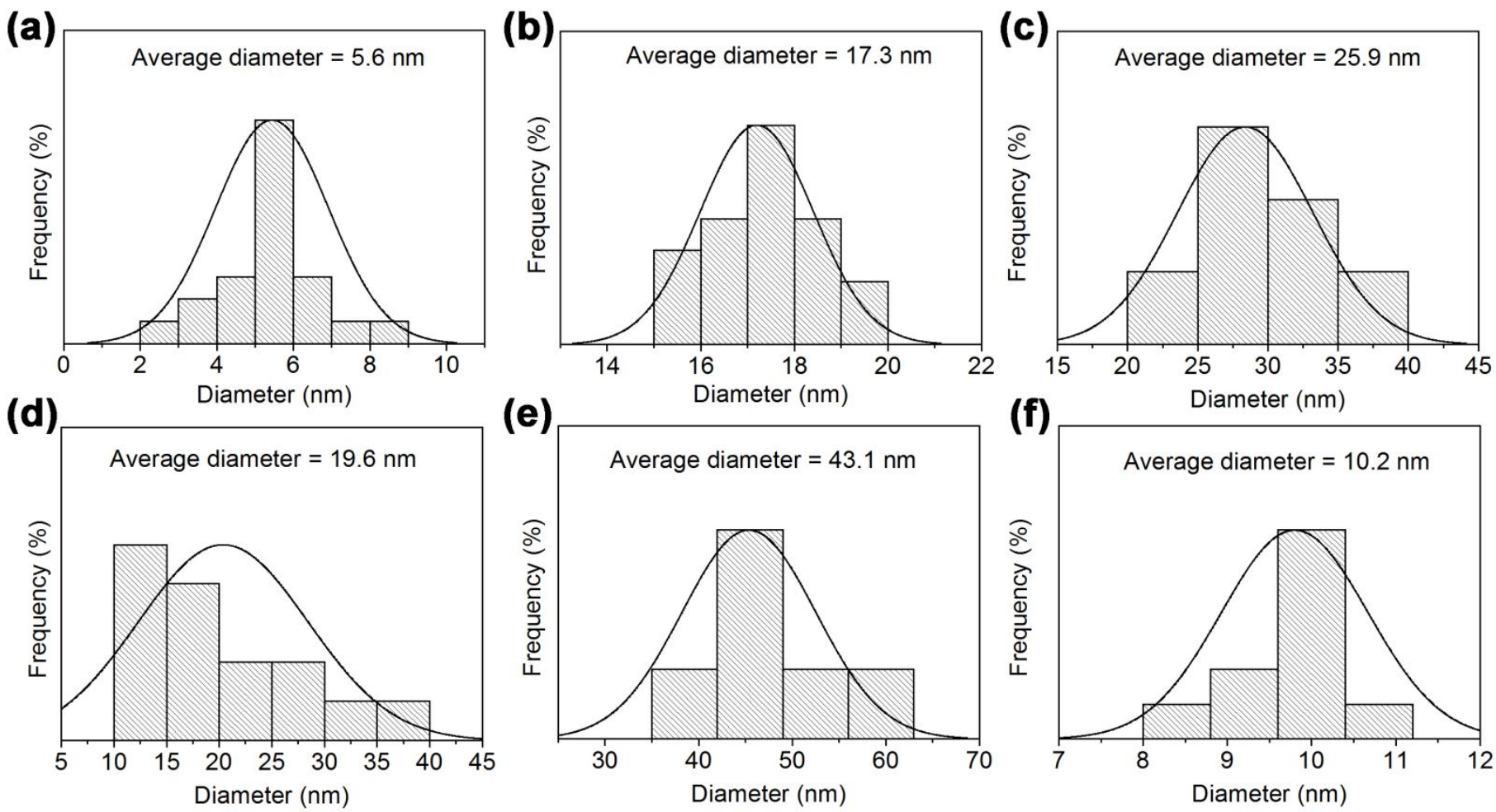

Fig. S9. The distributions of Pd particles of Pd/UiO-66- $\mathrm{NH}_{2}$ (a), Pd/HP UiO-66- $\mathrm{NH}_{2}$ (b), Pd cubes@HMOF-2-108 nm (c), Pd cubes@HMOF-2-43 nm (d), Pd cubes@HMOF-2-174 nm (e) and Pd cubes@HMOF-2-293 nm (f). 


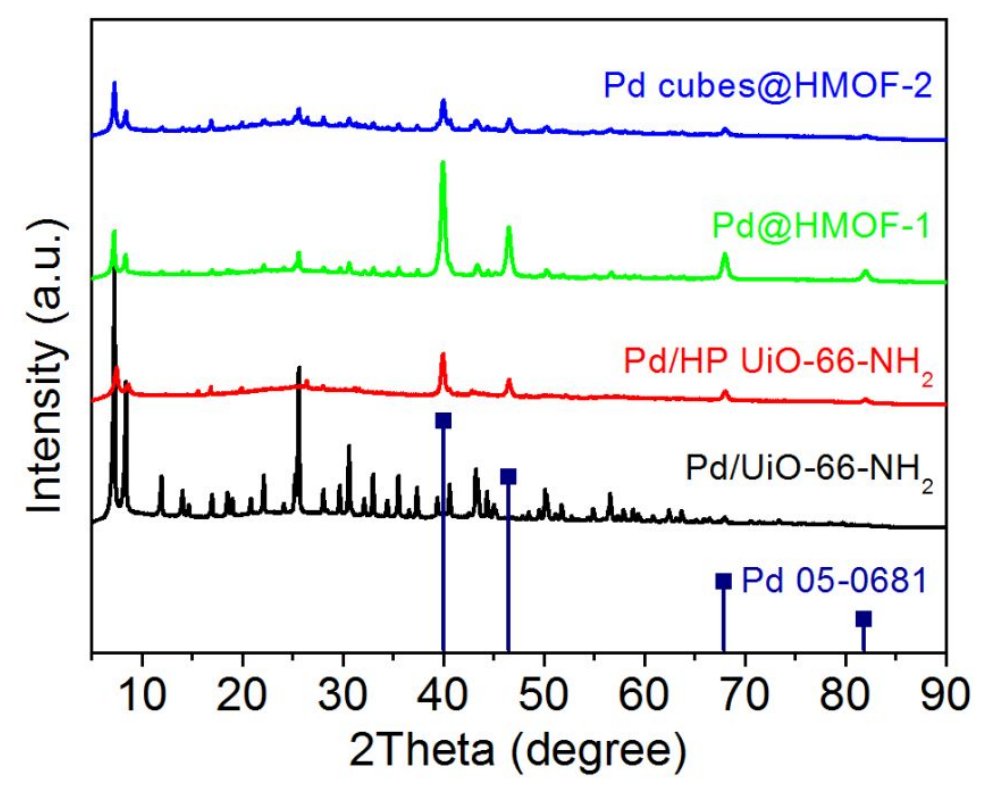

Fig.S10. XRD patterns of Pd (JCPDS no. 05-0681), Pd/UiO-66-NH 2 , Pd/HP UiO-66-NH2, Pd@HMOF-1 and Pd cubes@HMOF-2.
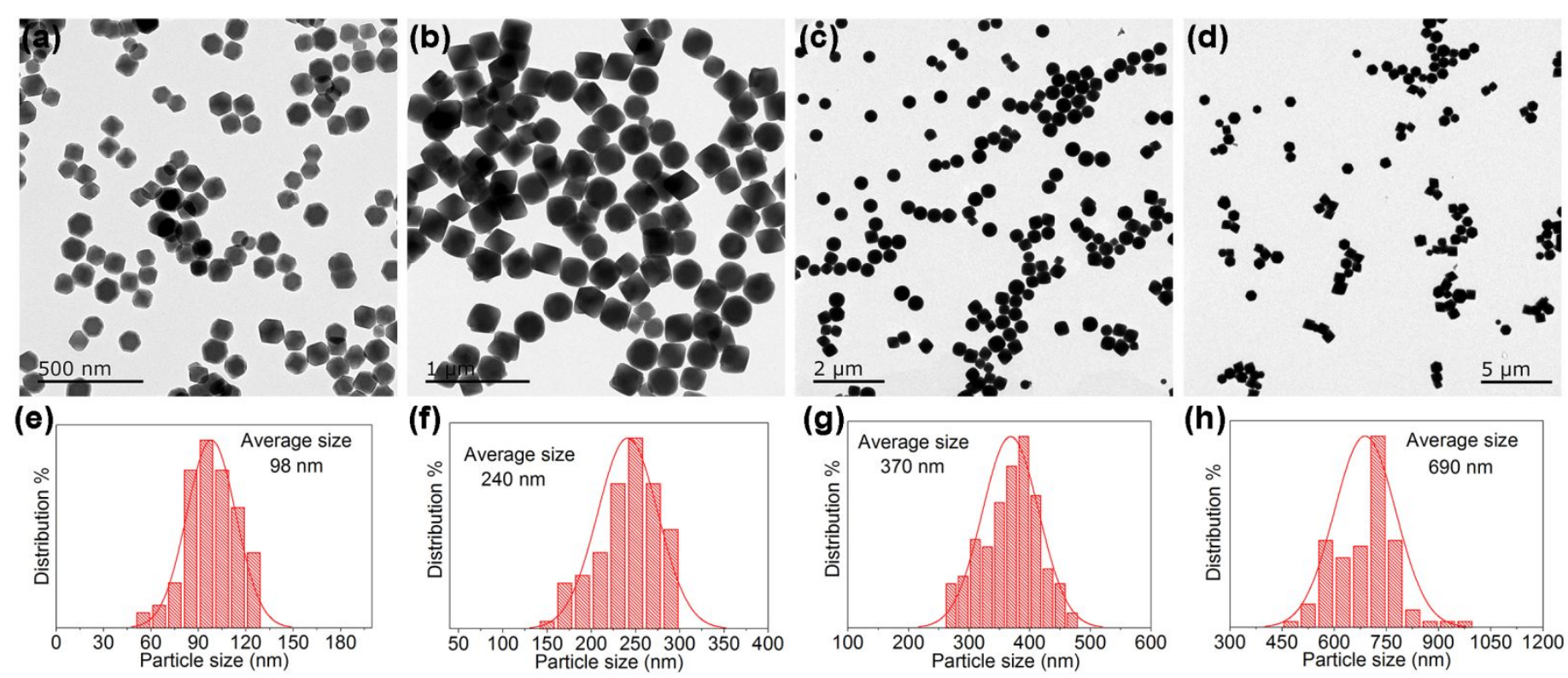

Fig.S11. TEM images of pristine UiO-66- $\mathrm{NH}_{2}$ octahedrons with different average particle sizes, $98 \mathrm{~nm}(\mathrm{a}), 240 \mathrm{~nm}$ (b), 370 $\mathrm{nm}(\mathrm{c})$ and $690 \mathrm{~nm}(\mathrm{~d})$. Corresponding particle size distributions (e-h). 


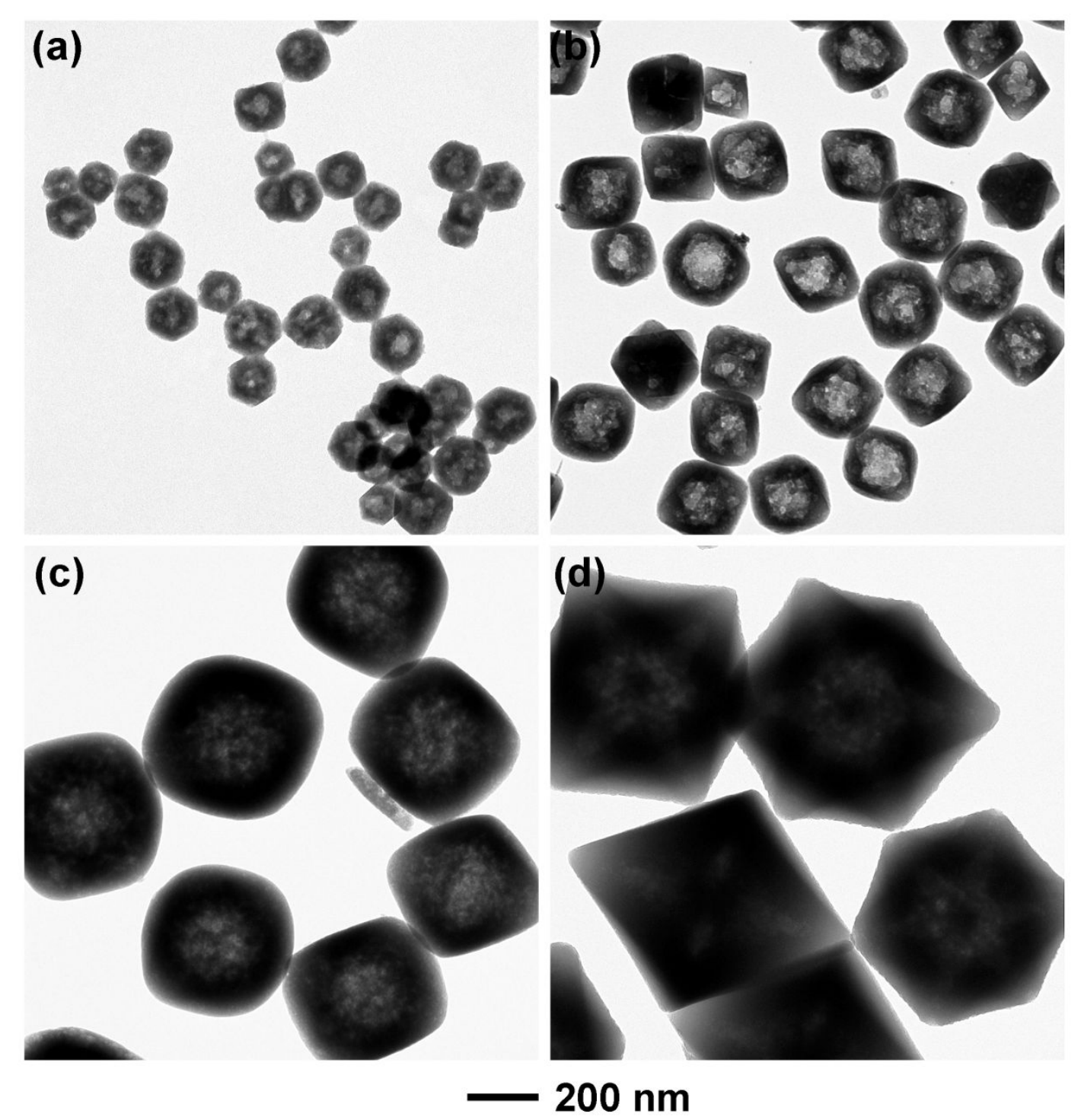

Fig.S12. TEM images of prepared HMOF-2 by digging holes on pristine UiO-66- $\mathrm{NH}_{2}$ shown in Fig. S10 with different sizes of internal space (43, 108, 174 and $293 \mathrm{~nm}$ respectively). 


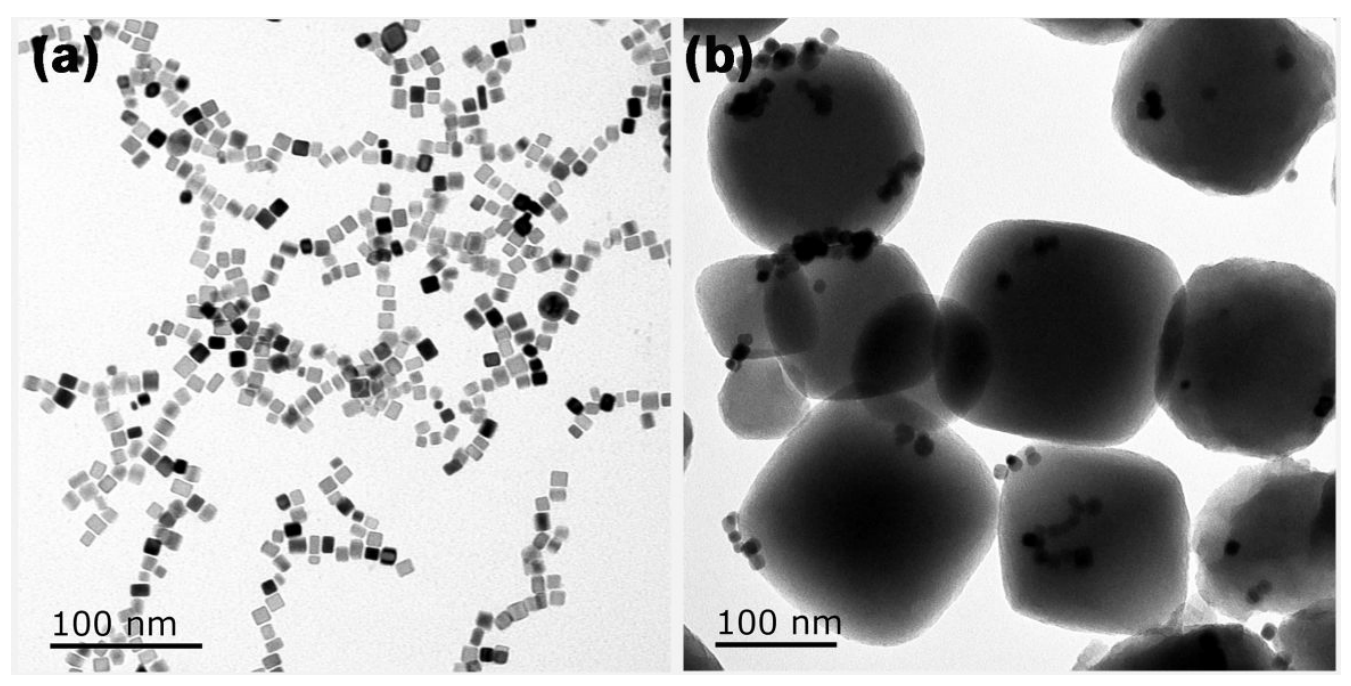

Fig.S13. TEM images of Pd cubes prepared in the absence of HMOFs (a) and Pd cubes/UiO-66-NH $\mathrm{N}_{2}(\mathrm{~b})$.

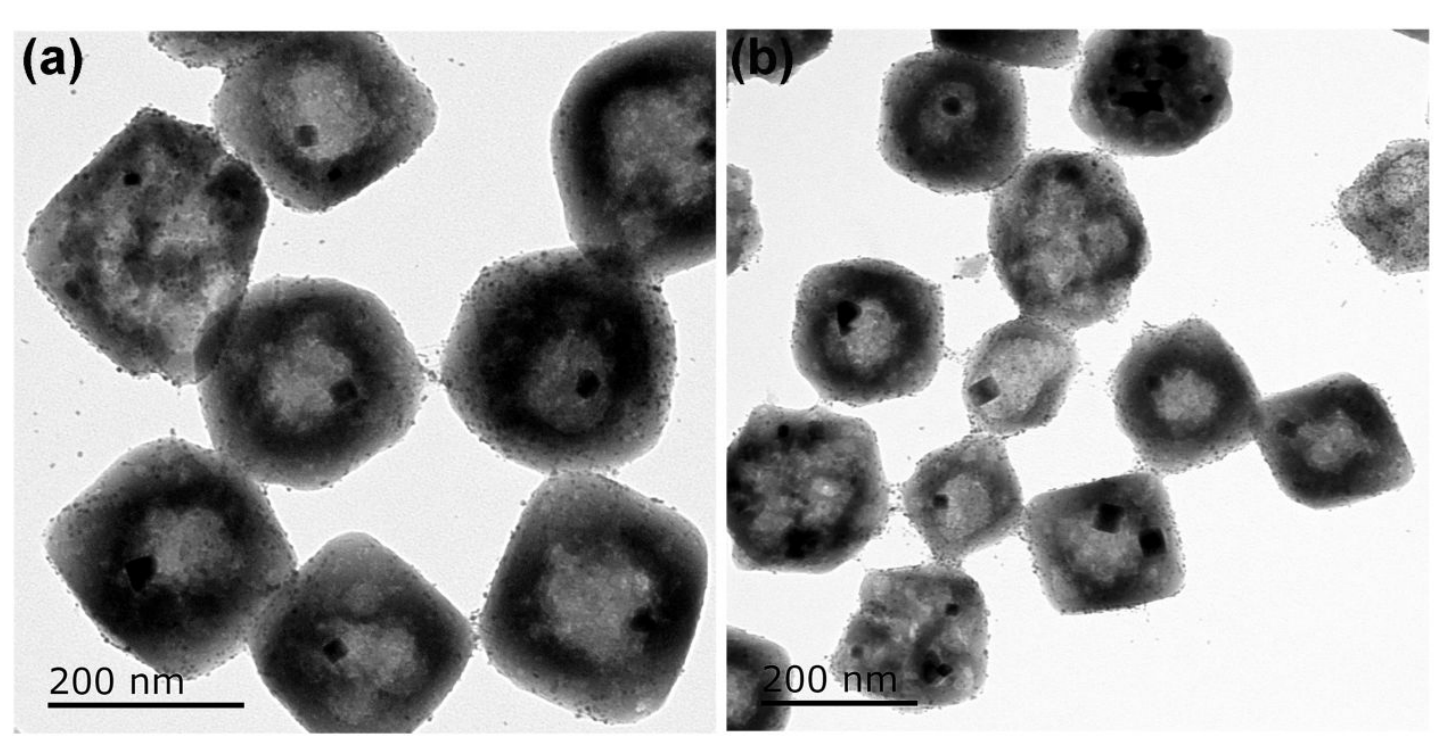

Fig.S14. TEM images of Pd cubes@HMOF-2 prepared at the condition of $0.05 \mathrm{mM} \mathrm{Na}_{2} \mathrm{PdCl}_{4}, 26.5 \mathrm{mg} \mathrm{PVP}, 75 \mathrm{mg} \mathrm{KBr}$, $15 \mathrm{mg}$ ascorbic acid and heated at $120^{\circ} \mathrm{C}(\mathrm{a}), 140{ }^{\circ} \mathrm{C}$ (b) in an oil bath for $3 \mathrm{~h}$. 


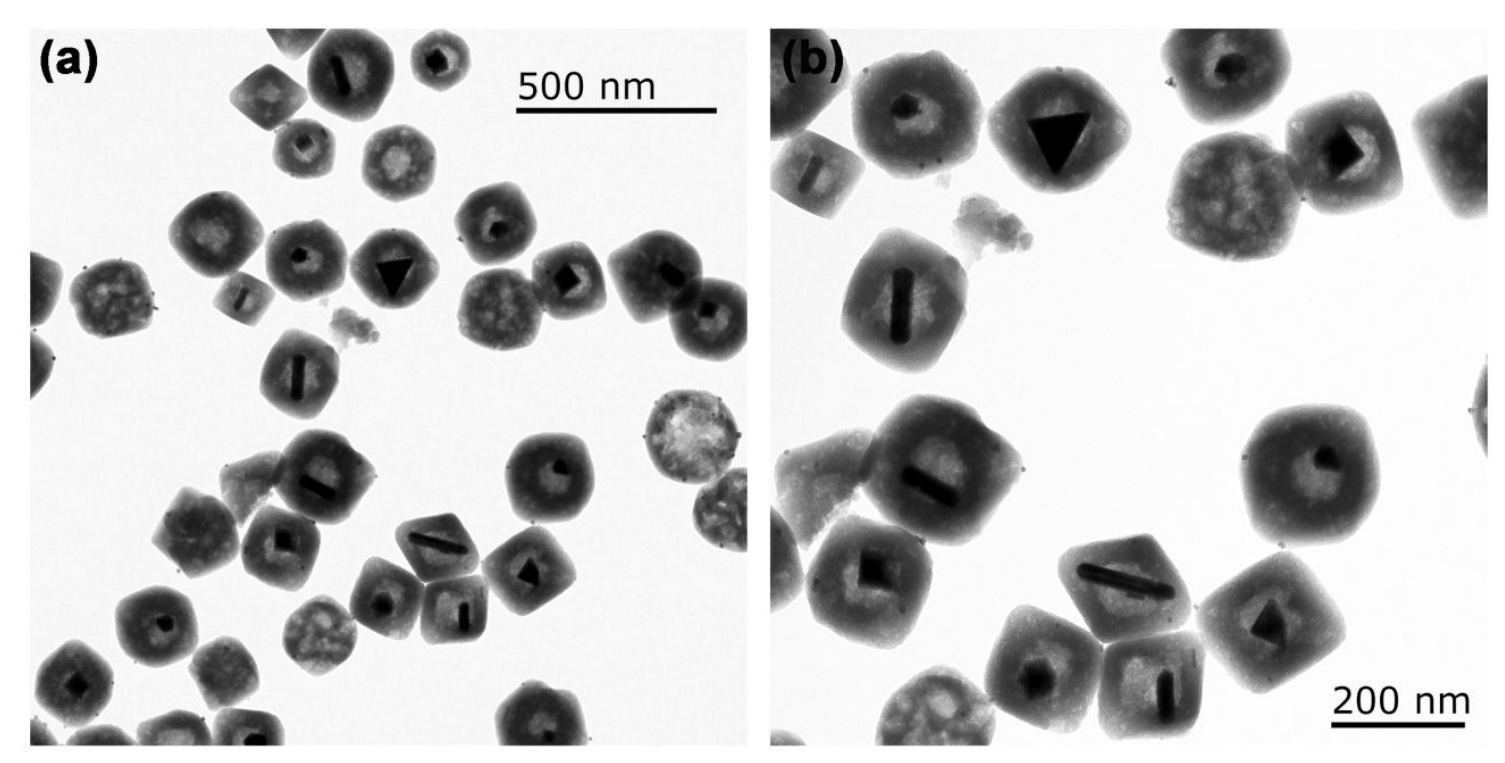

Fig.S15. TEM images of Pd rods\&triangular bipyramids@HMOF-2 prepared at standard preparation $\left(0.05 \mathrm{mM} \mathrm{Na}_{2} \mathrm{PdCl}_{4}\right.$, $26.5 \mathrm{mg}$ PVP, $600 \mathrm{mg} \mathrm{KBr}, 15 \mathrm{mg}$ ascorbic acid and heated at $80^{\circ} \mathrm{C}$ in an oil bath for $3 \mathrm{~h}$ ). 


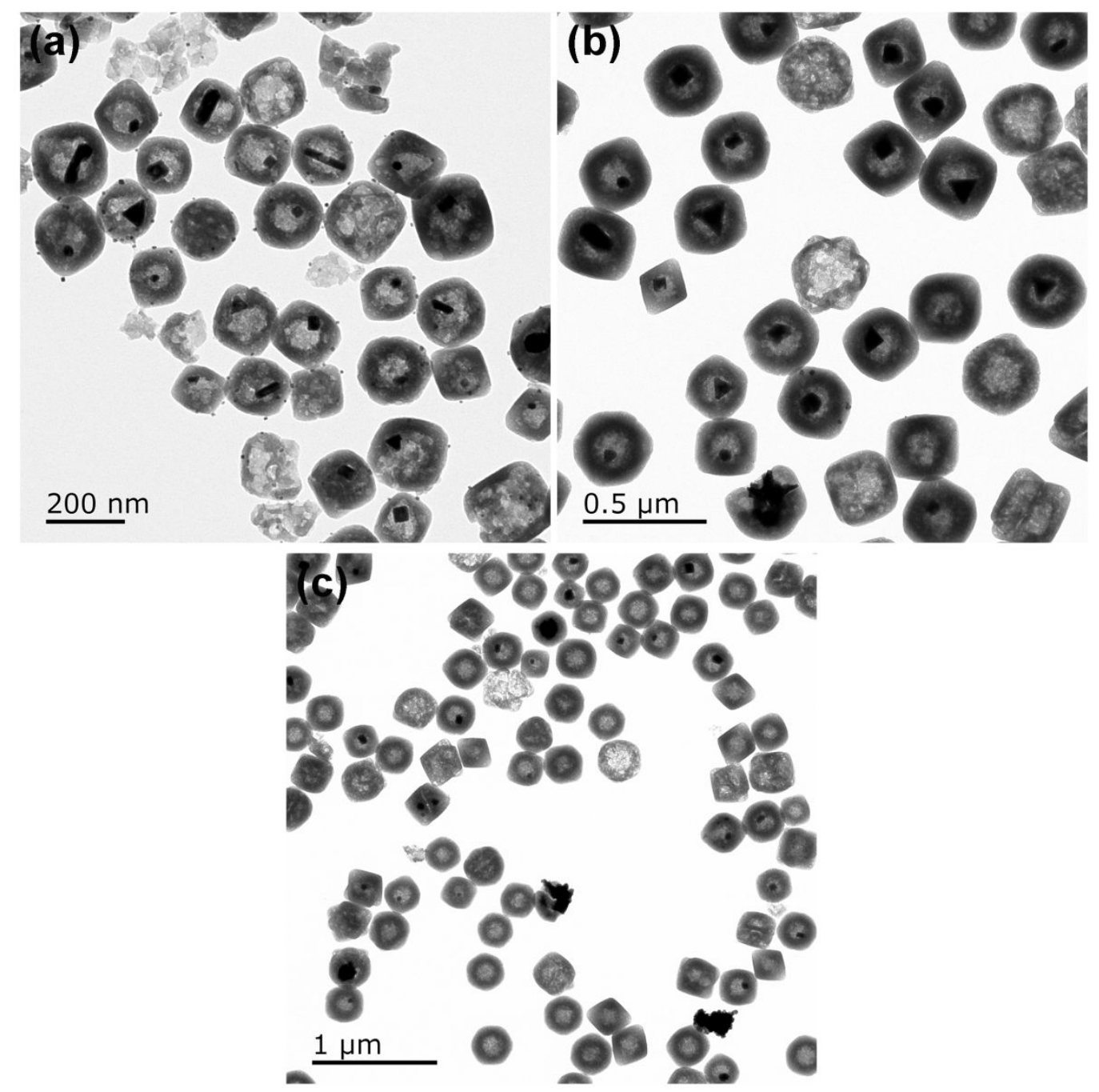

Fig.S16. TEM images of Pd rods\&triangular bipyramids@HMOF-2 prepared at the condition of $0.05 \mathrm{mM} \mathrm{Na}_{2} \mathrm{PdCl}_{4}, 26.5$ mg PVP, $15 \mathrm{mg}$ ascorbic acid, $300 \mathrm{mg}$ (a), $900 \mathrm{mg}$ (b) and $1200 \mathrm{mg}$ (c) of $\mathrm{KBr}$ and heated at $80^{\circ} \mathrm{C}$ in an oil bath for $3 \mathrm{~h}$. 


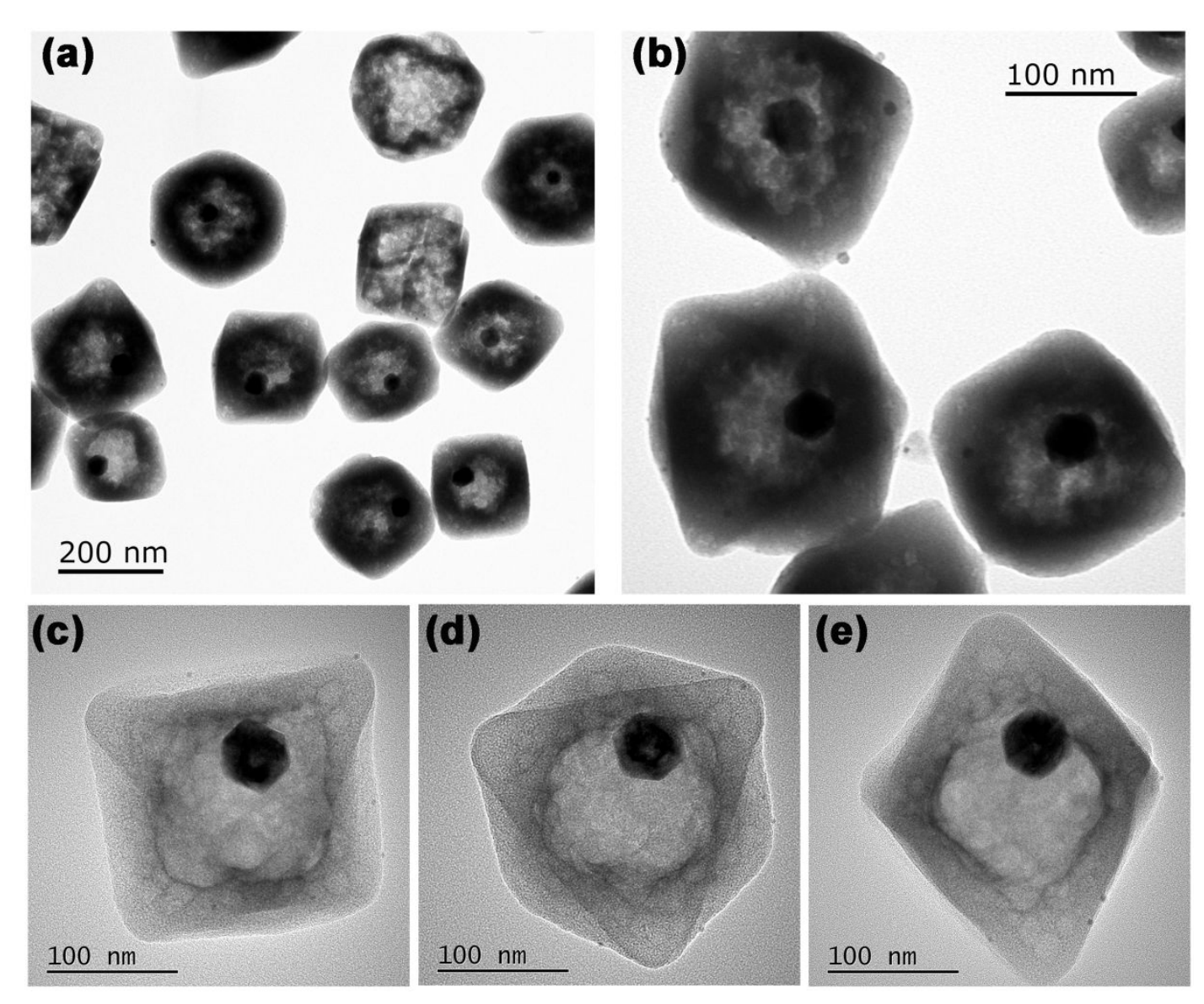

Fig.S17. TEM images of Pd icosahedrons@HMOF-2 prepared at standard preparation $\left(0.05 \mathrm{mM} \mathrm{Na}_{2} \mathrm{PdCl}_{4}, 26.5 \mathrm{mg} \mathrm{PVP}\right.$,

$74 \mathrm{mg} \mathrm{NaCl}, 15 \mathrm{mg}$ ascorbic acid and heated at $80^{\circ} \mathrm{C}$ in an oil bath for $3 \mathrm{~h}$ ) and HR-TEM images of single Pd icosahedrons@HMOF-2 hybrid at different tilting angles of $0^{\circ}(\mathrm{c}),-30^{\circ}(\mathrm{d})$ and $30^{\circ}(\mathrm{e})$ to show the icosahedral structure. 

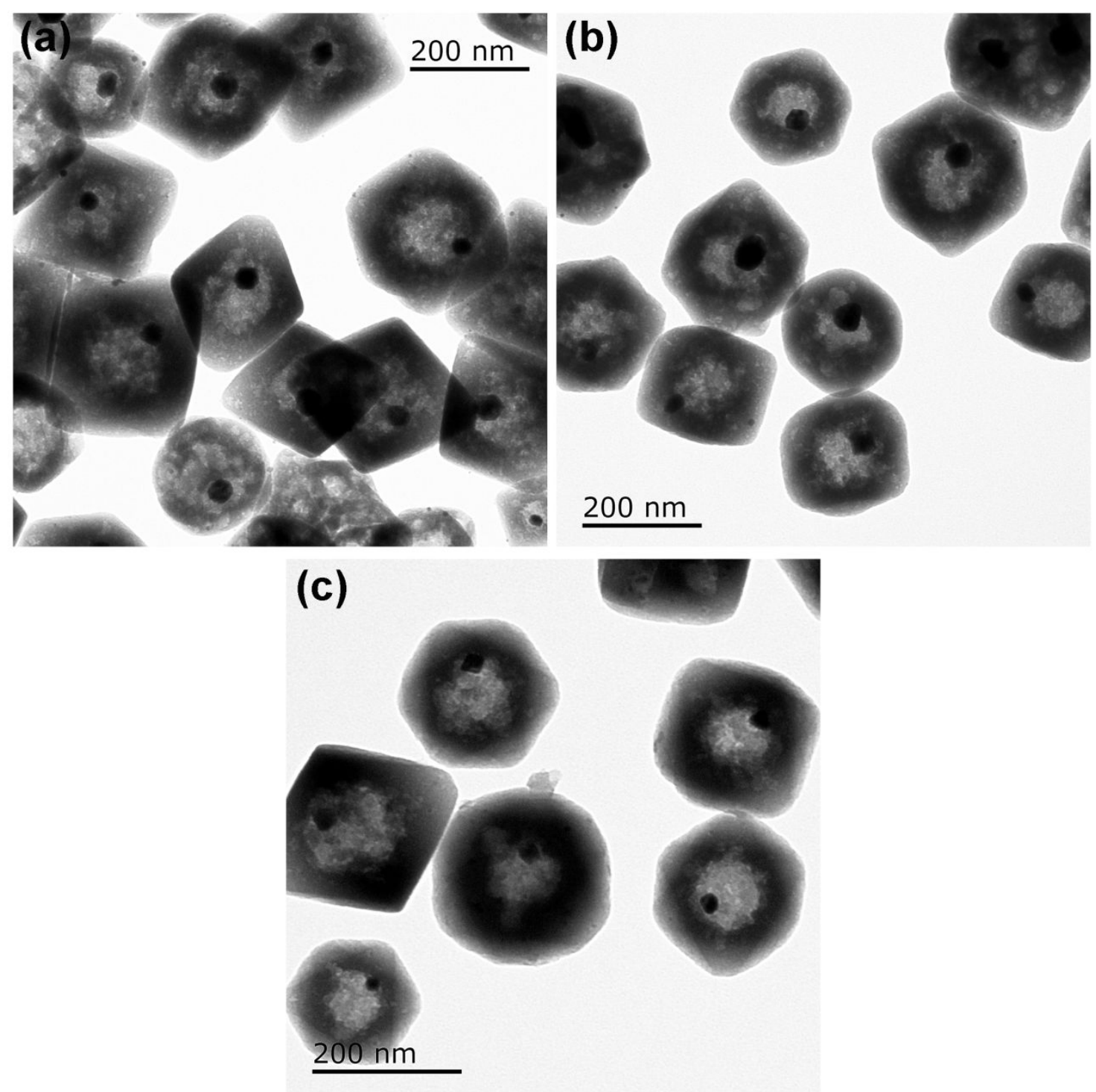

Fig.S18. TEM images of Pd icosahedrons@HMOF-2 prepared at the condition of $0.05 \mathrm{mM} \mathrm{Na}_{2} \mathrm{PdCl}_{4}, 26.5 \mathrm{mg} \mathrm{PVP}, 15 \mathrm{mg}$ ascorbic acid, $148 \mathrm{mg} \mathrm{NaCl}$ (a), $296 \mathrm{mg} \mathrm{NaCl}$ (b) and heated at $80^{\circ} \mathrm{C}$ in an oil bath for $3 \mathrm{~h}, 74 \mathrm{mg} \mathrm{KI}$ instead of $\mathrm{NaCl}$ in the standard Pd icosahedrons@HMOF-2 preparation (c). 


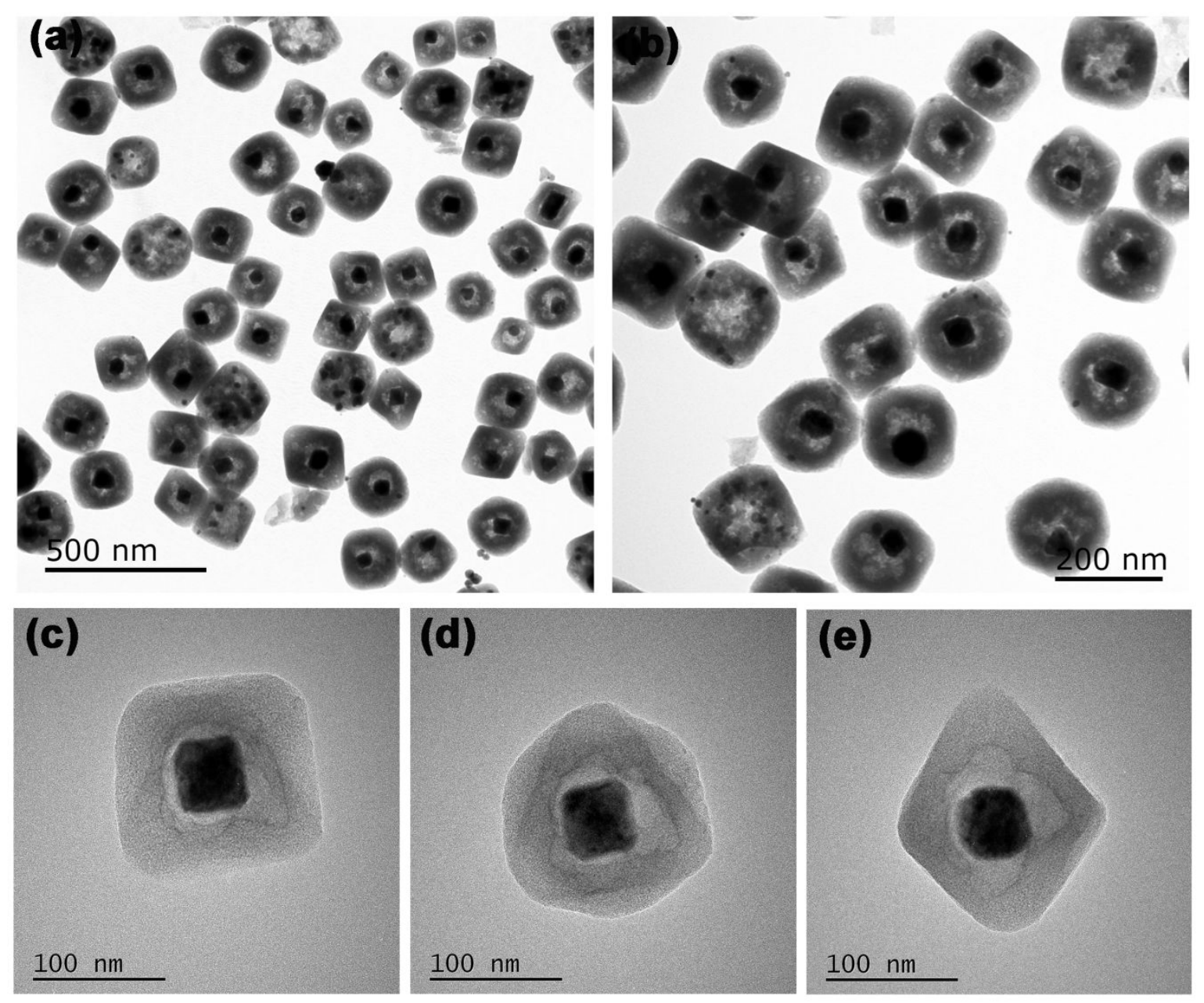

Fig.S19. TEM images of Pd truncated octahedrons@HMOF-2 prepared at standard preparation $\left(0.2 \mathrm{mM} \mathrm{Na}_{2} \mathrm{PdCl}_{4}, 106 \mathrm{mg}\right.$ PVP, $60 \mathrm{mg}$ citric acid monohydrate, $60 \mathrm{mg}$ ascorbic acid and heated at $60{ }^{\circ} \mathrm{C}$ in an oil bath for $16 \mathrm{~h}$ ) and HR-TEM images of single Pd truncated octahedrons@HMOF-2 hybrid at different tilting angles of $0^{\circ}(\mathrm{c}),-30^{\circ}(\mathrm{d})$ and $30^{\circ}$ (e) to show the truncated octahedral structure. 


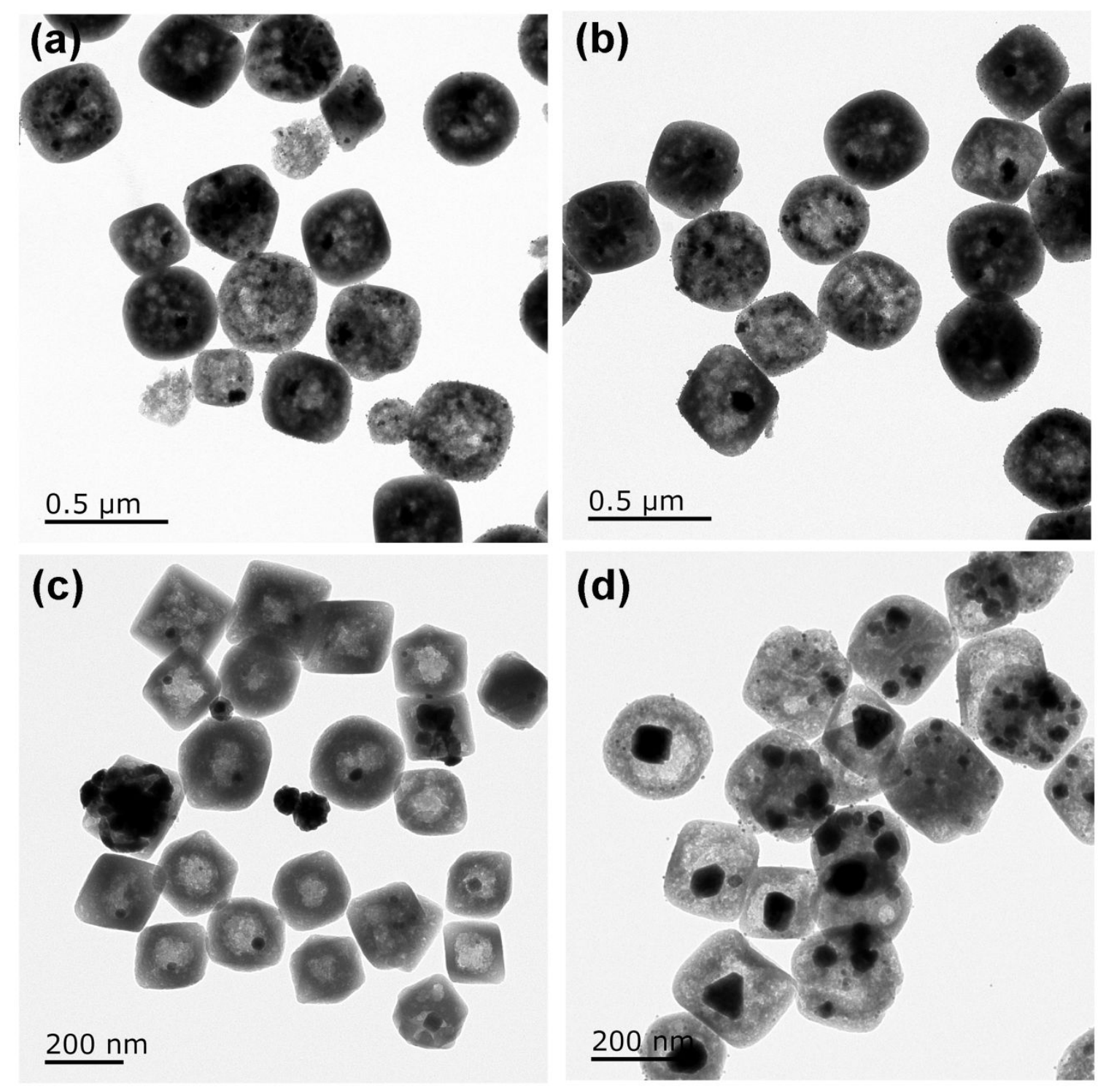

Fig.S20. TEM images of Pd truncated octahedrons@HMOF-2 prepared at the condition of $0.2 \mathrm{mM} \mathrm{Na}_{2} \mathrm{PdCl}_{4}, 106 \mathrm{mg}$ PVP, $60 \mathrm{mg}$ ascorbic acid, $30 \mathrm{mg}$ citric acid monohydrate (a), $60 \mathrm{mg}$ citric acid monohydrate and heated at $120^{\circ} \mathrm{C} \mathrm{(b)} \mathrm{in} \mathrm{an} \mathrm{oil}$ bath for $3 \mathrm{~h}, 25^{\circ} \mathrm{C}(\mathrm{c})$ and $80^{\circ} \mathrm{C}(\mathrm{d})$ instead of $45^{\circ} \mathrm{C}$ in the at standard $\mathrm{Pd}$ truncated octahedrons@HMOF-2 preparation. 


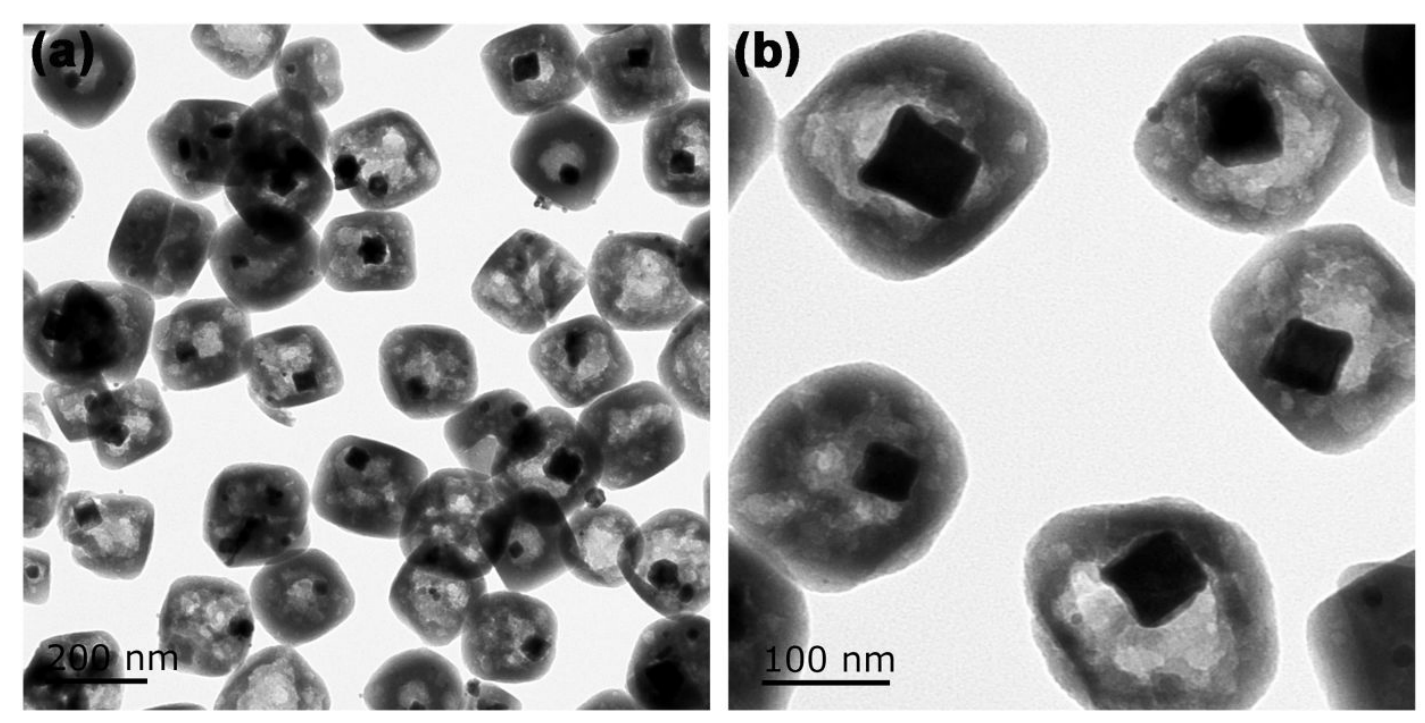

Fig.S21. TEM images of Pd concave cubes@HMOF-2 prepared at standard preparation $\left(0.2 \mathrm{mM} \mathrm{Na}_{2} \mathrm{PdCl}_{4}, 106 \mathrm{mg} \mathrm{PVP}\right.$ $(\mathrm{Mw}=40000), 60 \mathrm{mg}$ citric acid monohydrate, $60 \mathrm{mg}$ ascorbic acid and heated at $45{ }^{\circ} \mathrm{C}$ in an oil bath for $3 \mathrm{~h}$ ). 

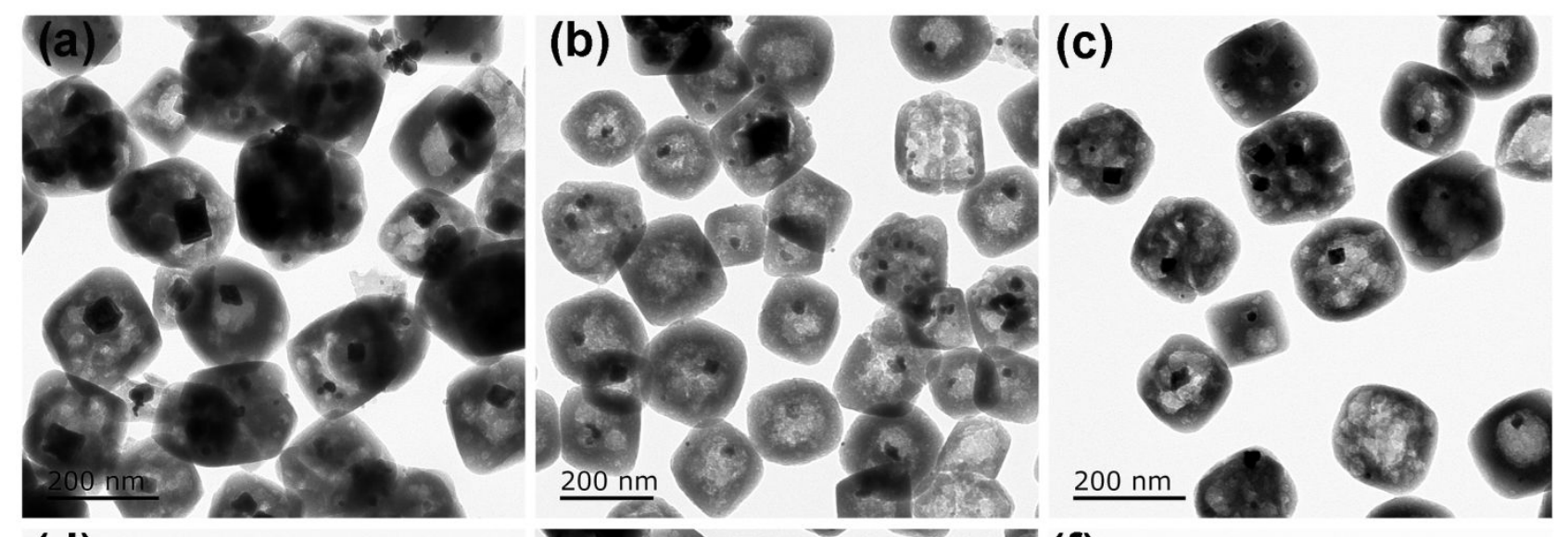

(d)

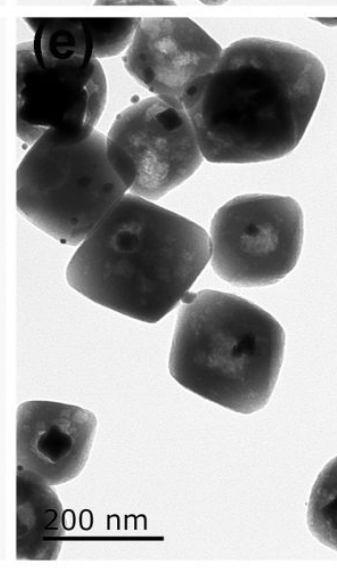

(f)
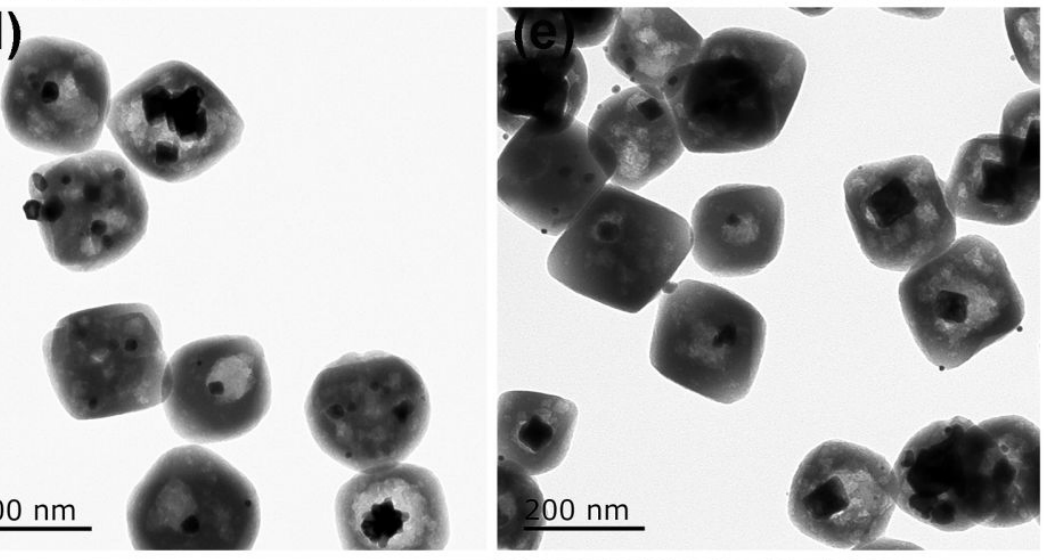

(g)

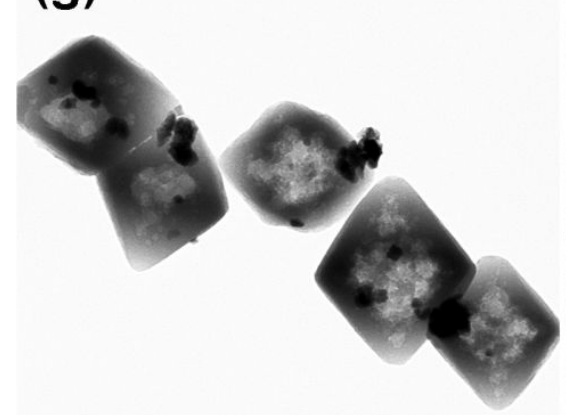

$\frac{200 \mathrm{~nm}}{\operatorname{man}}$
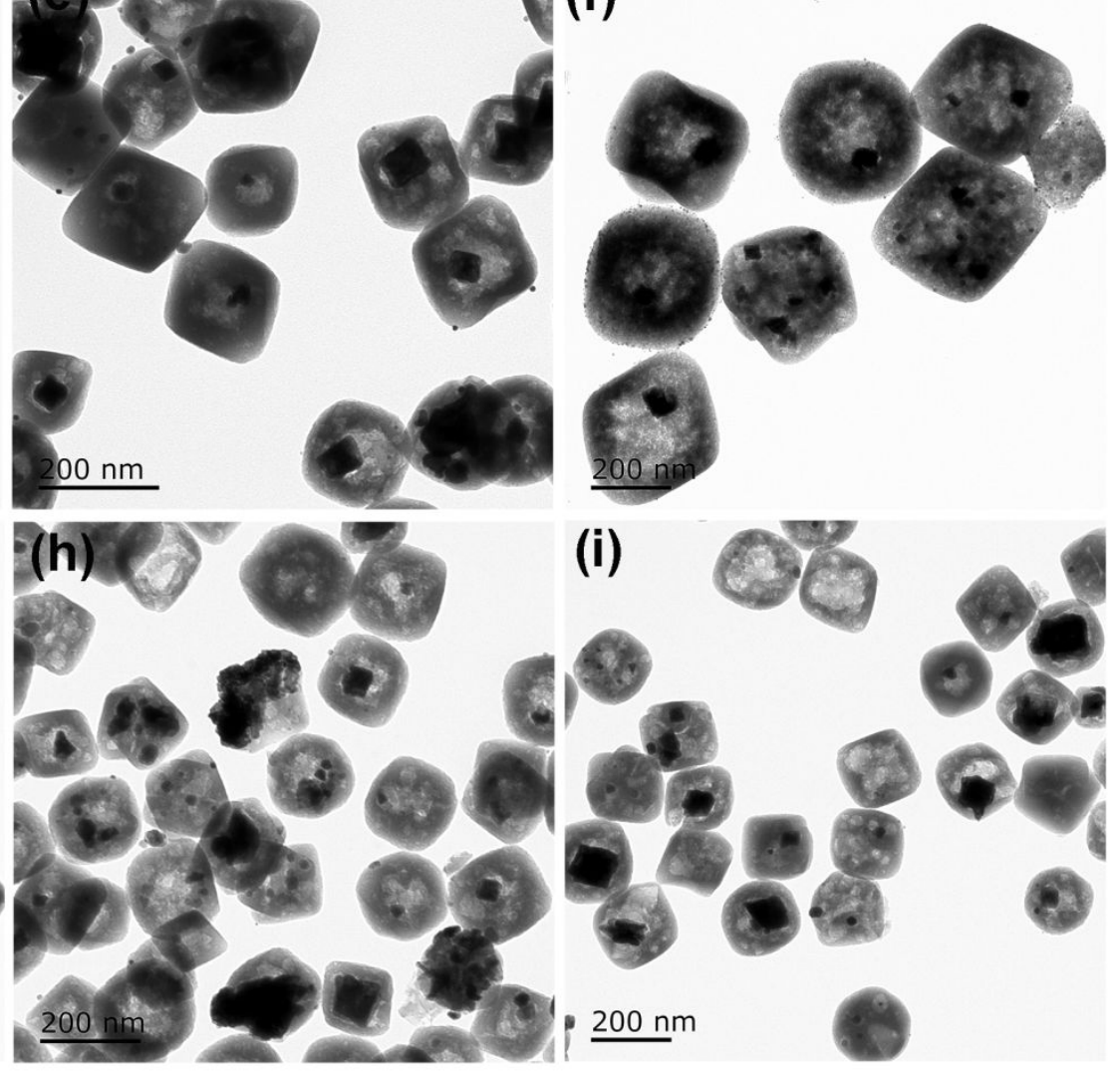

Fig.S22. TEM images of Pd concave cubes@HMOF-2 prepared at the condition of $0.1 \mathrm{mM}(\mathrm{a}), 0.05 \mathrm{mM}(\mathrm{b})$ and $0.025 \mathrm{mM}$

(c) $\mathrm{Na}_{2} \mathrm{PdCl}_{4}, 106 \mathrm{mg}$ PVP $(\mathrm{Mw}=55000), 60 \mathrm{mg}$ citric acid monohydrate, $60 \mathrm{mg}$ ascorbic acid and heated at $45^{\circ} \mathrm{C}$ in an oil bath for 3 h. $0.2 \mathrm{mM} \mathrm{Na}_{2} \mathrm{PdCl}_{4}, 106 \mathrm{mg}$ PVP (Mw = 40000), $60 \mathrm{mg}$ citric acid monohydrate, $60 \mathrm{mg}$ ascorbic acid and heated at $35^{\circ} \mathrm{C}(\mathrm{d}), 70^{\circ} \mathrm{C}(\mathrm{e}), 120^{\circ} \mathrm{C}(\mathrm{f})$ in an oil bath for $3 \mathrm{~h}$. CTAB substitute for PVP $(\mathrm{Mw}=55000)(\mathrm{g})$, the reaction time prolong to $16 \mathrm{~h}(\mathrm{~h}), 106 \mathrm{mg}$ PVP $(\mathrm{Mw}=40000)$ substitute for PVP $(\mathrm{Mw}=55000)$ (i) in the standard Pd concave cubes@HMOF-1-240nm preparation. 


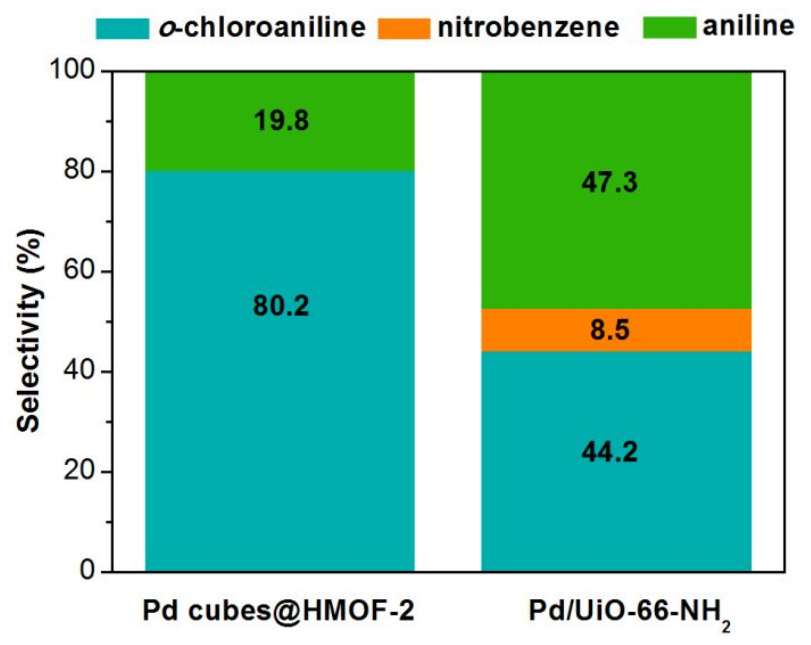

Fig.S23. Catalytic results of Pd cubes@HMOF-2 and Pd/UiO-66--NH $\mathrm{N}_{2}$ after 4 cycles.

Table S2. ICP-MS results of as-prepared samples.

\begin{tabular}{c|cc}
\hline Catalysts & Pd contents (ppm) & Pd (wt\%) \\
\hline Pd/UiO-66-NH ${ }_{2}$ & 4.22 & 4.22 \\
Pd/HP UiO-66-NH 2 & 5.01 & 5.01 \\
Pd@HMOF-1 & 12.78 & 12.78 \\
Pd cubes@HMOF-2 & 4.85 & 4.85 \\
Pd cubes@HMOF-2 (after four-cycle) & 4.72 & 4.72 \\
Pd rods\&triangular bipyramids@HMOF-2 & 4.68 & 4.68 \\
Pd truncated octahedrons@HMOF-2 & 7.23 & 7.23 \\
Pd icosahedrons@HMOF-2 & 4.85 & 4.85 \\
Pd concave cubes@HMOF-2 & 7.55 & 7.55 \\
Pd cubes/UiO-66-NH 2 & 3.14 & 3.14 \\
\hline
\end{tabular}

$5 \mathrm{mg}$ samples were digested by aqua regia then diluted in $50 \mathrm{~mL} 2 \% \mathrm{HNO}_{3}$ for detection. 
Table S3. Catalytic performances of as-prepared samples on hydrogenation of o-CNB.

\begin{tabular}{|c|c|c|c|c|c|c|c|c|}
\hline Catalysts & $\begin{array}{c}\mathrm{d}^{\mathrm{a}} \\
(\mathrm{nm})\end{array}$ & $\begin{array}{c}\mathrm{V}^{\mathrm{b}} \\
\left(10^{-21} \mathrm{~cm}^{3}\right)\end{array}$ & $\begin{array}{c}\rho \\
\left(\mathrm{g} / \mathrm{cm}^{3}\right)\end{array}$ & $\begin{array}{c}\mathrm{m}^{\mathrm{c}} \\
\left(10^{-15} \mathrm{mg}\right)\end{array}$ & $\begin{array}{c}\mathrm{N}^{\mathrm{d}} \\
\left(10^{12}\right)\end{array}$ & $\begin{array}{c}\mathrm{n} \\
\left(10^{-11} \mathrm{~mol}\right)\end{array}$ & $\begin{array}{c}\mathrm{TOF}^{\mathrm{e}} \\
\left(\mathrm{s}^{-1}\right)\end{array}$ & $\begin{array}{c}\mathrm{TOF}_{\text {-specific }}{ }^{\mathrm{f}} \\
\left(\mathrm{s}^{-1}\right)\end{array}$ \\
\hline $\mathrm{Pd} / \mathrm{UiO}-66-\mathrm{NH}_{2}$ & 5.6 & 92 & 12.02 & 1.1 & 383 & 63.6 & 3 & 0.03 \\
\hline $\mathrm{Pd} / \mathrm{HP}$ UiO-66- $\mathrm{NH}_{2}$ & 17.3 & 2704 & 12.02 & 32.5 & 15.4 & 2.56 & 56 & 0.06 \\
\hline Pd cubes@HMOF-2 & 25.9 & 17374 & 12.02 & 208.8 & 2.3 & 0.382 & 604 & 0.15 \\
\hline $\mathrm{Pd}$ cubes/UiO-66- $\mathrm{NH}_{2}$ & 10.8 & 1260 & 12.02 & 15.1 & 20.8 & 3.455 & 63 & 0.09 \\
\hline
\end{tabular}

${ }^{a}$ Average diameter of $\mathrm{Pd}$ particles for the sample of $\mathrm{Pd} / \mathrm{UiO}-66-\mathrm{NH}_{2}$ and $\mathrm{Pd} / \mathrm{HP} \mathrm{UiO}-66-\mathrm{NH}_{2}$, average side length of $\mathrm{Pd}$

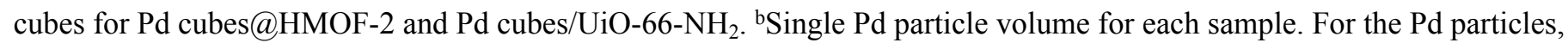

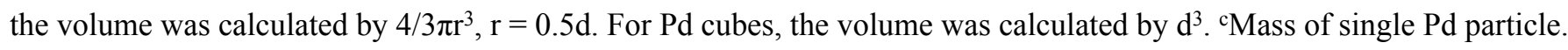

${ }^{\mathrm{d} N u m b e r}$ of Pd particles. ${ }^{\mathrm{e}} \mathrm{TOF}$ define as the transformed $\mathrm{n}(\mathrm{o}-\mathrm{CNB}) / \mathrm{n}(\mathrm{Pd})$ per second, $\mathrm{n}(\mathrm{Pd})$ represents the molar of $\mathrm{Pd}$ particles. fSpecific catalytic efficiency that is derived by normalizing TOF against the surface area of an individual catalyst.

Table S4. Catalytic performances comparison of previous and our results.

\begin{tabular}{|c|c|c|c|}
\hline \multirow{2}{*}{ Catalysts } & \multicolumn{3}{|c|}{ Selectivity $(\%)$} \\
\hline & $o$-chloroaniline & nitrobenzen & aniline \\
\hline $\mathrm{Pd} / \mathrm{RGO}^{\mathrm{S} 1}$ & 66.9 & & \\
\hline $\mathrm{Pd} / \mathrm{AC}^{\mathrm{S} 1}$ & 44.3 & & \\
\hline $\mathrm{Pd} / \mathrm{o}-\mathrm{CNTS}_{\mathrm{s}}^{\mathrm{S} 1}$ & 59.3 & & \\
\hline $\mathrm{Pd} / \mathrm{C}^{\mathrm{S} 2}$ & 45.7 & $<1.5$ & 52.8 \\
\hline OAPE-5 $5^{\mathrm{S} 3}$ & 3.42 & 44.2 & 36.6 \\
\hline $\mathrm{Pd} / \mathrm{TiO}_{2}-\mathrm{C}^{\mathrm{S} 4}$ & 59 & $<3$ & 38 \\
\hline Pd cubes@HMOF-2 in this work & 83.6 & - & 16.4 \\
\hline Pd cubes@HMOF-2 (after 4 cycles) & 80.2 & - & 19.8 \\
\hline
\end{tabular}

${ }^{\text {aT }}$ The total percent of nitrobenzene and aniline.

(S1) Zhang, X.; Qu, N.; Fan, Q.; Yang, H.; Liu, A. Palladium nanoparticles hosted in graphene-based 2-dimension polyelectrolyte brushes for enhanced hydrogenation selectivity of o-chloronitrobenzene. Appl. Surf. Sci. 2019, 485, 230-237.

(S2) Su, C.; Li, X.; Zhang, Q.; Ma, L.; Lu, C.; Feng, F. Behavior of adsorbed diphenyl-sulfide on the Pd/C catalyst for o-chloronitrobenzene hydrogenation. Chinese Chem. Lett. 2013, 24, 59-62.

(S3) Liang, C.; Han, J.; Shen, K.; Wang, L. Zhao, D.; Freeman, H. S. Palladium nanoparticle microemulsions: Formation and use in catalytic hydrogenation of o-chloronitrobenzene. Chem. Eng. J. 2010, $165,709-713$.

(S4) Sikhwivhilu, L.; Coville, N.; Pulimaddi, B.; Venkatreddy, J.; Vishwanathan, V. Selective hydrogenation of o-chloronitrobenzene over palladium supported nanotubular titanium dioxide derived catalysts. Catal. Commun. 2007, 8, 1999-2006. 